\title{
Epidemiologi ved juvenil systemisk lupus erythematosus (JSLE)
}

\author{
Odd Vinje og Berit Flatø \\ Revmatologisk avdeling, Rikshospitalet
}

\section{ENGLISH SUMMARY}

\author{
Vinje $\mathrm{O}$, Flatø B. The epidemiology of juvenile systemic lupus erythematosus. \\ Nor J Epidemiol 2008; 18 (1): 83-85.
}

\begin{abstract}
There are major uncertainties concerning the frequency of juvenile systemic lupus erythematosus in the different populations in the world. The incidence is reported to be between 0.36 and $0.9 / 1,00,000$ per year. However, there exist great differences between different ethnic populations. The frequency is particularly high in African blacks and some Asian populations, and least frequent in white Caucasians. The disease is very infrequent before the age of 5 . The great majority gets the disease after the age of 8 , median age about 12 years. There is a female overrepresentation, most prominent in the older age group. The risk of early death has decreased significantly during the latest 40-50 years. Published data from the 1950s and 1960s yields 5 -year survival rates of only 17.5 to $60 \%$. Five- and 10 years survival rates are now approaching $100 \%$ and $90 \%$. How it will turn out after 20,30, 40 and 50 years of disease is unknown. Severe kidney affection, particularly grade 4 or 5 glomerulonephritis is historically most closely associated with early death. But also CNS disease, high general disease activity, severe infection and low social status increase the risk. The risk of severe infection, sepsis, seems to parallel the increase of effective treatment. Irreversible organ damage in different organs also seems to have increased in the latest decade, and might be associated with increasing survival, often as a result of more aggressive medical treatment.
\end{abstract}

JSLE er en kronisk, fluktuerende, autoimmun, flerorgansykdom av ukjent årsak. Den kjennetegnes ved at det opptrer betennelse av blodkar og bindevev i en rekke organer med varierende lokalisering og alvorlighetsgrad. Positiv ANA er nesten alltid til stede, mens positiv nativt anti-DNA og SM-antigen har høy spesifisitet for sykdommen.

\section{KLASSIFIKASJON}

\section{ACR-kriteria 1982 (1)}

- Sommerfuglutslett

- Discoid lupus utslett

- Fotosensibilitet

- Slimhinnesår, munn eller nese

- Ikke erosiv eller deformerende artritt (2 eller flere ledd)

- Nefritt (proteinuri $>0,5 \mathrm{~g} / 24 \mathrm{~h}$ og/eller kornede eller erytrocyttsylindere)

- Krampe og/eller psykose

- Pleuritt eller pericarditt

- Cytopeni (hemolytisk anemi, og/eller leukopeni og/eller lymfopeni og/eller trombocytopeni

- Positiv nativt DNA eller SM og/eller positiv Le-test

- Positiv ANA

\section{ACR Modifisert 1997 (2)}

- Sommerfuglutslett

- Discoid lupus utslett

- Fotosensibilitet

- Slimhinnesår, munn eller nese
- Ikke erosiv eller deformerende artritt (2 eller flere ledd)

- Nefritt (proteinuri > 0,5 g/24h og/eller kornede eller erytrocyttsylindere)

- Krampe og/eller psykose

- Pleuritt eller pericarditt

- Cytopeni (hemolytisk anemi, og/eller leukopeni og/eller lymfopeni og/eller trombocytopeni

- Positiv nativt DNA eller SM og/eller positiv antifosfolipid-antistoff: IgG eller IgM, lupus antikoagulant og/eller falsk positiv serologisk syfilis test $>6$ måneder

- Positiv ANA

Klassifiseringskriteriene er ment å brukes på pasienter som allerede har fått stilt diagnosen SLE. ACR modifiserte kriterier anbefales brukt. I mangel på definerte diagnosekriterier blir klassifikasjonskriteriene imidlertid også ofte brukt som dette. Evaluering av ACR 1982 kriteriene hos barn har vist $96 \%$ sensitivitet og 100\% spesifisitet ved tilstedeværelse av 4 av 11 kriterier (3).

\section{INSIDENS OG PREVALENS}

Det finnes sparsomt med data om insidens og prevalens av SLE hos barn.

\section{Insidens}

I en undersøkelse fra sørlige Sverige i perioden 19811986 rapporteres det om en insidens pr. år i aldersgruppen under 15 år på 0,4 pr. 100.000 barn (4). Studier i Canada indikerer en årlig insidens pr. 100.000 
barn på 0,36 (5) og i Finland på 0,37 og $0,9(6,7)$. Fra Japan er det rapportert en insidens på 0,47 (8). Den kanadiske studien (5) kan være den mest pålitelige fordi alle pasienter som ble innlemmet $\mathrm{i}$ aktuelle register hadde på forhånd blitt vurdert og diagnose verifisert av barnerevmatolog (9). Lilleby et al. (10) registrerte fra 1980 til 2002 til sammen 77 nye pasienter med SLE i Norge. Dette tilsvarer 3,5 nye tilfeller pr. år eller 0,39/100 000 pr. år.

De fleste undersøkelser hos voksne med SLE viser en høyere insidens hos mørkhudede og asiater enn hos hvite. Tidligere undersøkelser av barn med SLE har indikert det samme (11-13).

\section{Prevalens}

Lehman rapporterer at preliminære estimater for prevalens blant jenter i ulike etniske grupperinger $i$ aldersgruppen 10-18 år i USA er som følger: asiater 31, svarte 20, "hispanics" 13 og hvite 4/100.000 (14). Fra barnerevmatologiske sykdomsregistre i Canada, Storbritannia og USA og rapporteres det om at SLE utgjør henholdsvis $<1 \%, 1,5-3 \%$ og $4,5 \%$ av pasientene $(5$, 15,16).

\section{KJØNNSFORDELING}

De fleste studier har rapportert om overvekt av jenter, 4-5:1, ved sykdomsdebut $i$ aldersgruppen $>10$ år, men liten kjønnsforskjell under 10 år $(17,18)$. Imidlertid ble det $i$ en større studie av JSLE ikke funnet noen signifikant kjønnsforskjell ved sykdomsdebut verken under eller over 10 år (19).

\section{SYKDOMSDEBUT}

I retrospektive undersøkelser fra Frankrike og Canada rapporteres det om median debut av JSLE på 12 år, og med sykdomsdebut hos de aller fleste fra 8 år og oppover. Sykdommen er meget sjelden før 5 år (20-22). Det er estimert at $15-20 \%$ av pasienter med SLE debuterer før 16 års alder (23).

\section{GENETIKK}

Kunnskapen her er i stor grad basert på undersøkelser hos voksne med SLE.

\section{Prognose/Mortalitet}

Risiko for tidlig død på grunn av sykdommen har bedret seg betydelig de siste tiårene. Mens publiserte data fra 1950-1960-årene opererer med 5 års overlevelserate på 17,5-69\% viser undersøkelser fra 1980 og 1990 årene en 5 og 10 års overlevelserate på henholdsvis $59-93 \%$ og 28-86\% (24). Rapporter etter tusenårskiftet indikerer at 5 års overlevelse nå nærmer seg $100 \%$ og 10 års overlevelse nær 90\% $(25,26)$. Miettunen et al. (25) rapportere om $100 \%$ overlevelse hos 51 pasienter med juvenil SLE etter 5 år og 85,5\% overlevelse etter 10 år. Femten av disse var hvite, de resterende asiater eller annen etnisk bakgrunn. Ingen afrikanere. I motsetning til de fleste tidligere studier rapporterte de ingen assosiasjon med kjønn eller etnisk bakgrunn når det gjaldt morbiditet eller mortalitet. Lilleby et al. (10) fant at 4 av 77 pasienter var døde etter 2-20 års oppfølgning.

Historisk sett har alvorlig nyreaffeksjon gitt størst risiko for tidlig død, men også CNS-affeksjon, generell høy sykdomsaktivitet, alvorlige infeksjoner og lav sosialstatus øker risikoen. Hagelberg et al. (27) har i en retrospektiv undersøkelse undersøkt hvordan nyreaffeksjon påvirker morbiditet og mortalitet hos $66 \mathrm{ka}-$ nadiske barn med biopsiverifisert nefritt. Blant pasienter med diffus glomerulonefritt, WHO klasse 4 nefritt, de fleste behandlet med azathioprin eller cyclofosfamid, var 10 og 19 års mortalitetsrate på $9 \%$ og $12 \%$. Hvite kaukasier hadde bedre prognose enn ikkekaukasier. For 15 pasienter med ren mesangial nefritt, WHO klasse 2, og 8 pasienter med fokal segmental eller fokal proliferativ nefritt, WHO klasse 3, var det ingen dødsfall ved follow-up på inntil 21 år, gjennomsnittlig 11 år. Det siste 10-året er imidlertid sepsis rapportert å erstatte nyresvikt som viktigste dødsårsak (28). En årsak til dette kan være mer aggressiv immunosuppressiv behandling.

De seneste 10 årene har skade ("organ damage") kommet mer i sentrum. "Organ damage" er definert som irreversibel forandring $\mathrm{i}$ organsystem som har vært til stede i mer enn seks måneder, og er rapportert hos 50,5-61\% av pasientene (25,29-31). Lilleby et al. (10) rapporterte organ damage hos $61 \%$ av 71 pasienter med gjennomsnittlig sykdomsvarighet på 10,8 år. De hyppigste skadeområdene var CNS (nevropsykiatriske symptomer og funn), nyrer og muskelskjelettapparatet. Hypertensjon, lang sykdomsvarighet og bruk av cyclofosfamid hadde høyest assosiasjon til skade. Økende overlevelse er trolig en viktig grunn til at man observer slik høy frekvens av skade det siste 10-året.

\section{KONKLUSJON}

Insidens og prevalens av juvenil SLE er usikker. I de fleste studier rapporteres det en insidens på mellom 0,36 og 0,4 pr. 100.000 barn/år. Sykdommen opptrer sjelden før 5 års alder. De fleste får sykdommen fra 8 år og oppover, median ca. 12 år. Det er overvekt av jenter, mest uttalt i den eldre aldersgruppen. Risiko for tidlig død på grunn av sykdommen har sunket vesentlig de siste 40-50 årene. På 50-60 tallet rapporteres det om 5 års overlevelserate på 17,5-60\%. Fem og 10 års overlevelserate nærmer seg nå 100\% og 90\%. Hvordan situasjonen vil være etter 20,30, 40, 50 års sykdom i forhold til den vanlige populasjon vites ikke. Alvorlig nyreaffeksjon har historisk gitt størst risiko for tidlig død, men også CNS-affeksjon, generell høy sykdomsaktivitet, alvorlige infeksjoner og lav sosialstatus øker risikoen. Risiko for alvorlige infeksjoner synes å ha øket i takt med effektiv medisinsk behandling. Varige skader etter sykdom i ulike organsystemer synes å ha øket, og kan ha sammenheng med økende overlevelse ofte etter aggressiv medisinsk behandling. 


\section{REFERANSER}

1. Tan EM, Cohen AS, Fries JF et al. The 1982 revised criteria for the diagnosis of lupus erythematosus. Arthritis Rheum 1982; 25: 1271-7.

2. Hochberg MC. Updating of American College of Rheumatology revised criteria for the classification of systemic lupus erythematosus. Arthritis Rheum 1997; 40: 1725.

3. Ferraz MB, Goldenberg J, Hilario MO et al. Evaluation of the 1982 ARA lupus criteria data set in pediatric patients. Clin Exp Rheumatol 1994; 12: 83-7.

4. Johnson H, Nived O, Sturfeldt G, Siman A. Estimating the incidence of systemic lupus erythematosus in a defined population using multiple sources of retrieval. Br J Rheumatol 1990; 29: 185-8.

5. Malleson PN, Fung MY, Rosenberg AM. The incidens of rheumatic pediatric diseases: results from the Canadian Pediatric Rheumatology Assosiation Disease Registry. J Rheumatol 1994; 21: 1981-7.

6. Pelkonen PM, Jalanko HJ, Lantto RR et al. Incidence of systemic connective tissue disease in children: a nationwide propective study in Finland. J Rheumatol 1994; 21: 2143-6.

7. Kaipiainen-Sappanen O, Savolainen A. Incidence of chronic rheumatic diseases in Finland during 1980-1990. Clin Exp Rheumatol 1996; 14: 441-4.

8. Fujikawa S, Okuni M. A national surveillance study of rheumatic diseases among Japanese children. Acta Paediatr Jap 1997; 39: 242-4.

9. Cassidy JT, Petty RE, Laxer RML, Lindley BB. Textbook of pediatric rheumatology, fifth edition, chapter 16. Elsevier Saunders, Philadephia.

10. Lilleby V, Flato B, Forre O. Disease duration, hypertension and medication requirements are associated with organ damage in childhood-onset systemic lupus erythematosus. Clin Exp Rheumatol 2005; 23: 261-9.

11. King KK, Kornreich HK, Bernstein BH et al. The clinical spectrum of systemic lupus erythematosus in children. Arthritis Rheum 1977; 20 (suppl): 315-22.

12. Meislin AG, Rothfield NF. Systemic lupus erythematosus in childhood: analysis of 42 cases with comparative data from 200 adult cases followed concurrently. Pediatrics 1968; 42: 37-49.

13. Walravens PA, Chase HP. The prognosis of childhood systemic lupus erythematosus. Am J Dis Child 1976; 130: 929-33.

14. Lehman TJA. Systemic lupus erythematosus in children. UpToDate oktober 2007.

15. Symmons DPM, Jones M, Osborne J et al. Pediatric rheumatology in UK: data from the British Pediatric Rheumatology Group National Diagnostic Register. J Rheumatol 1997; 23: 1975-80.

16. Bowyer S, Roettcher P, the members of the Pediatric Rheumatology Database Research group. Paediatric rheumatology clinic populations in the United States results of a 3 year survey. J Rheumatol 1996; 23: 1968-74.

17. Norris DG, Colon AR, Stickler GB. Systemic lupus erythematosus in children: the complex problem of diagnosis and treatment encountered in 101 such patient at the Mayo Clinic. Clin Pediatr 1977; 16: 774-8.

18. Celemajor DS, Thorner PS, Baumal R, Arbus GS. Sex differences in childhood lupus nephritis. Am J Dis Child 1984; 138: 586-8.

19. King KK, Kornreich HK, Bernstein BH et al. The clinical spectrum of systemic lupus erythematosus in childhood. Arthritis Rheum 1977; 20 (2 suppl): 287-94.

20. Lehman TJ, McCurdy DK, Bernstein BH et al. Systemic lupus erythematosus in the first decade of life. Pediatrics 1989; 83: 235-9.

21. Bader-Meunier B, Armengaud JB, Haddad E et al. Initial presentation of childhood-onset systemic lupus erythematosus: a French multicenter study. J Pediatr 2005; 146: 648-53.

22. Benseler SM, Silverman ED. Systemic lupus erythematosus. Pediatr Clin North Am 2005; 52: 443-67.

23. Stichweh D, Arce E, Pascual V. Update on pediatric lupus erythematosus. Curr Opin Rheumatol 2004; 16: $577-87$.

24. Ravelli A, Ruperto N, Martini A. Outcome in juvenile systemic lupus erythematosus. Curr Opin Rheumatol 2005; 17: 568-73.

25. Miettunen PM, Ortiz-Alvarez O, Petty RE et al. Gender and ethnic origin have no effect on longterm outcome of childhood-onset systemic lupus erythematosus. J Rheumatol 2004; 31: 1650-4.

26. Perfumo F, Martini A. Lupus nephritis in children. Lupus 2005; 14: 83-8.

27. Hagelberg S, Lee Y, Bergman J et al. Longterm followup of children with lupus nephritis. J Rheumatol 2002; 29: $2635-42$.

28. Wang LC, Yang YH, Lu MY, Chang BL. Retrospective analysis of mortality and morbidity of pediatric systemic lupus erythematosus in the past two decades. J Microbiol Immunol Infect 2003; 36: 203-8.

29. Brunner HI, Siverman ED, To T et al. Risk factors for damage in childhood-onset systemic lupus erythematosus: cumulative disease activity and medication use predict disease damage. Arthritis Rheum 2002; 46: 436-44.

30. Brunner HI, Silverman ED, Bombardier C, Feldman BM. European Consensus Lupus Activity Measurement is sensitive to change in disease activity in childhood-onset systemic lupus erythematosus. Arthritis Rheum 2003; 49: 335-41.

31. Ravelli A, Duarte-Salazar C, Buratti S et al. Assessment of damage in in juvenile-onset lupus erythematosus: a multicenter cohort study. Arthritis Rheum 2003; 49: 501-7. 